\title{
New distributional records of Cleome rutidosperma DC. and Ruellia simplex C.Wright for Tripura, India
}

\author{
Somnath Kar'1, Aparajita Das², Dipti Das ${ }^{3}$ and B. K. Datta ${ }^{2}$ \\ ${ }^{1}$ Communicating author:Department of Botany Holy Cross College, Lembucherra, 799210 \\ E-mail: somnathagt21@gmail.com \\ ${ }^{2}$ Plant Taxonomy and Biodiversity Laboratory, Department of Botany, Tripura University, \\ Suryamaninagar-799022, Tripura, India \\ ${ }^{3}$ Department of Botany ,Netaji Subhash Mahavidyalaya, Udaipur, 799120, Tripura, India
}

[Received 13.11.2019; Revised 15.12.2019; Accepted 16.12.2019; Published 31.12.2019]

\begin{abstract}
The occurrence of two angiospermic species Cleome rutidosperma DC. (Cleomaceae) and Ruellia simplex C.Wright (Acanthaceae) in different places of Tripura are recorded as their extended distribution as well as naturalization in the state of Tripura in North-east India.
\end{abstract}

Key words: Cleome rutidosperma, Ruellia simplex, New distribution, Tripura

\section{INTRODUCTION}

The flora of any region is always changing due to inward and outward migration of different species. At the same time forced introduction of many species as crop or ornamental or any type of useful plants is also a continuous process through different anthropogenic activities. Many weedy plants also reach to other localities through natural migration or accidentally by human (Das 2002, 2011; McDougall 2011).

Tripura, the second smallest state of North-eastern India is surrounded by Bangladesh in three sides and situated between $23^{\circ} 302$ to $23^{\circ} 442 \mathrm{~N}$ latitudes and between $91^{\circ} 152$ to $91^{\circ} 282$ E longitudes (Kar \& Datta, 2015). It is positioned at the convergence of Indo-Burman biogeographical zone (Rao 1994) and part of the IUCN recognized IndoBurma Biodiversity Hotspots (Myers 2000; Mittermeier et al. 2005). The undulating topography, high rainfall and varied altitudes are main factors that have contributed to its rich hilly ecosystemand habitat diversity.

Deb $(1981,1983)$ studied the flora of Tripura state with later additions. During continuous field survey $(2016$ - 2019), recently two plants were collected from different parts of the state and were identified as Cleome rutidosperma DC. and Ruellia simplex C.Wright using different literature including Flora of India (Sharma \& Balakrishnan 1993), Flora of West Bengal (Anonymous 1997), e-floras, http://www.flowersofindia.net/catalog. Both of these species are exotics for the flora of India. While Cleome rutidosperma is a weedy plant native of tropical Africa and now distributing as an invasive weed in tropical areas (Anonymous 1997; Biswas \& Das 2019).On the other hand, Ruellia simplex, a native of South-Tropical America is introduced to many countries as an ornamental almost in all tropical countries (https://sites.google.com/site/efloraofindia/species/a-1/a/ acanthaceae/ruellia/ruellia-brittoniana). The evidence of garden or crop plants escaping 
and naturalized is not rare (Moktan \& Das 2013; Biswas \& Das 2013) and generally cause international concern (IUCN 2000).

Present paper deals with the reports the occurrence of two species in the North-east Indian state Tripura along with their description and photographs. The voucher specimens has been deposited in the Tripura University Herbarium.

\section{TAXONOMIC TREATMENT:}

Cleome rutidosperma DC., Prodr. 1:241.1824; Ansari, F1. Kasaragod Div. 61. 1985; Sundararagh. in B.D. Sharma \& N.P. Balakr., Fl. India 2: 313. 1993; R. Sundara. \& N.P. Balakr. in P. Daniel, Fl. Kerala 1: 243. 2005; Sunil \& Sivadasan, Fl. Alappuzha Dist. 93. 2009. [CLEOMACEAE] [Plate - I; Figures A - D]

\section{Vernacular name: Fringed Spider Flower, Neelavela}

Herbs, annual or rarely perennial, $30-100 \mathrm{~cm}$ tall. Stems sparsely branched, often with decumbent branches, glabrous or glabrescent to slightly scabrous (sometimes glandularpubescent); leaves trifoliate; stipules $0.1-0.5 \mathrm{~mm}$ long, scaly or absent; petioles $5-35$ $\mathrm{mm}$, proximally winged; leaflets ovate-lanceolate to rhomboid-elliptic, $10-35 \times 5-18$ $\mathrm{mm}$, entire or serrulate-ciliate, acute to obtuse or sometimes acuminate, abaxially with curved trichomes on veins especially when young, adaxially glabrous.Lower flowers axillarysolitary, gradually run into a 3 - 6-flowered raceme; bracts leafy, 3-foliate, $10-35 \mathrm{~mm}$; pedicels $1.1-2.2 \mathrm{~cm}$ elongate to $1.8-3.0 \mathrm{~cm}$ in fruit; Sepals yellow, narrowly lanceolate, $2-4 \times 0.2-0.3 \mathrm{~mm}$, persistent, glabrous, margin ciliated; petals white or speckled with purple, oblong to narrowly ovate, $7.0-9.5 \times 1.5-2.3 \mathrm{~mm}$, central 2 petals outside with a yellow transverse band; filaments yellow, $5-7 \mathrm{~mm}$; anthers purplish brown, $1-2 \mathrm{~mm}$;pistil $2-3 \mathrm{~mm}$ long, glabrous; style $0.5-1.4 \mathrm{~mm}$ long; ovary with distinct gynophore that elongate in fruits, $4-12 \mathrm{~mm}$; capsules $40-70 \times 3-4 \mathrm{~mm}$, striate. Seeds $8-24$ per capsule, reddish brown to black with white funicular aril, $1-1.5 \mathrm{~mm}$, slender, striately verrucose.

Habitat:The species grows as a weed in disturbed and ruderal habitats, primarily in areas with humid and hot environmental conditions; prefer calcareous habitat like walls.

Flowering \& Fruiting: April - December.

Specimens examined: Tripura, Tripura University, Kar et al., TUH-2728, dated 09.10.2017.

Distribution: A native of Mexico, the Caribbean, and South America. InAsia: Bangladesh, India, Malaysia, Maldives, Myanmar, Philippines, Sri Lanka, Thailand; North America; South America; Africa.

Indian Distribution: Andaman \& Nicobar Islands, Assam, Bihar, Gujarat, Karnataka, Kerala, Maharashtra, Tamil Nadu, Tripura, Uttar Pradesh, West Bengal.

State distribution: Throughout the state of Tripura.

Use: Leaves are used to make soups (Grubben \& Denton 2004). The plant is an appetizer and laxative.

Ruellia simplex C.Wright,Anales Acad. Ci. Med. Habana (6) 41: 321. 1870. Type: Cuba. En sabanas abajas y frangosas ca. del Hato "El Salado," jurisdiccion de San Cristóbal y Palacios, 21 December 1860, C. Wright 3642 (Holotype: GH[00094208]). [ACANTHACEAE] [Plate - I; Figures E \& F] 

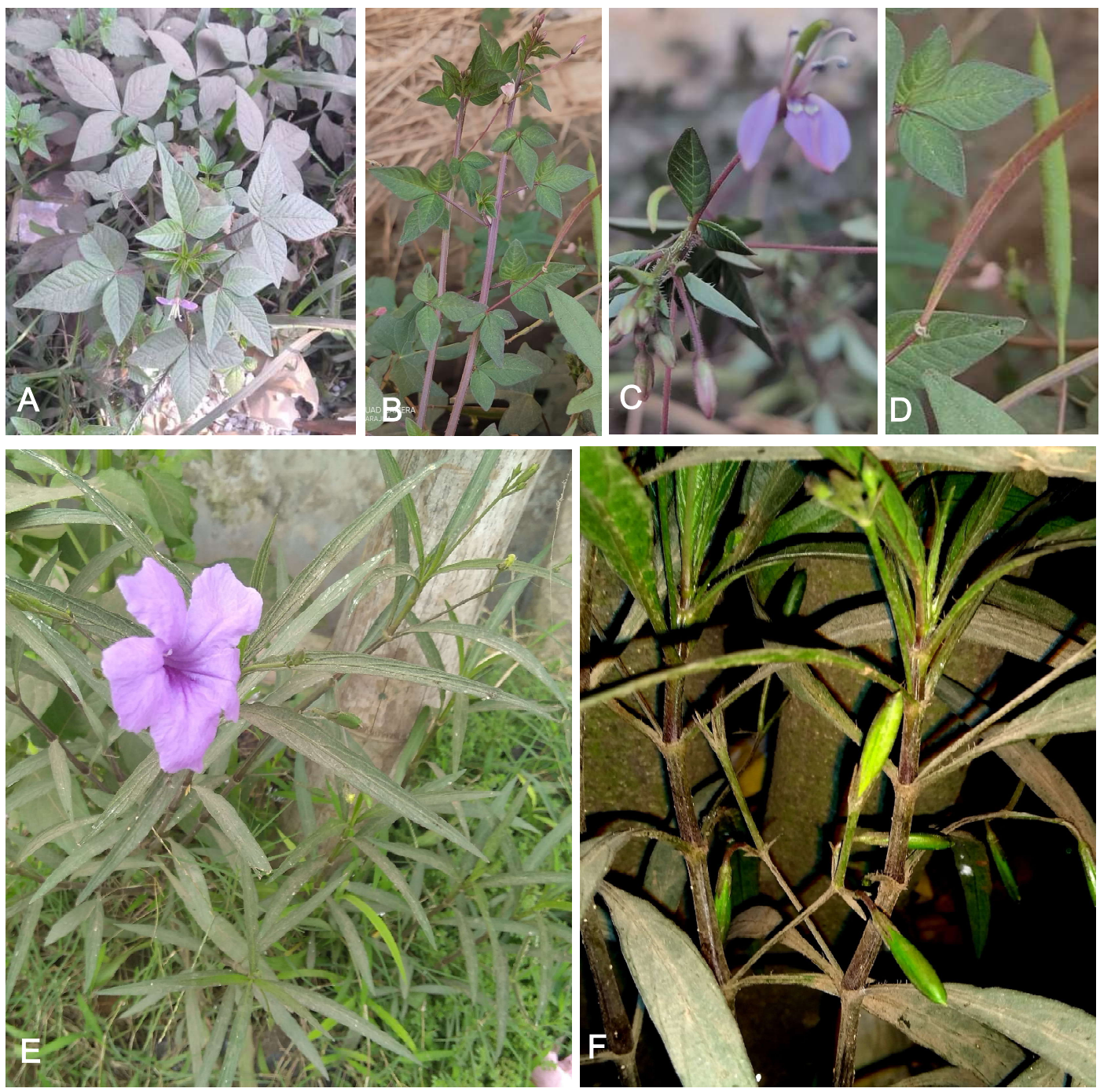

PLATE - I. A - D. Cleome rutidosperma DC. [A \& B. Flowering Plant; C. Flower; D. Fruits]; E - F. Ruellia simplex C. Wright [R. Plant flower; F. Plant with fruit]

Common name: Mexican petunia, Mexican bluebell, Britton's wild petunia

Perennialherbs or under-shrubs;stem erect or prostrate to decumbent;older stems often slightly woody, younger stems green,4-angled, glabrous or sparsely puberulent, often with prominent tufts of hairs at nodes.Leavesopposite;petiole missing or upto $20 \mathrm{~mm}$ long; lamina linear to narrowly oblong, $15.0-30.0 \mathrm{~cm} \times 1.3-1.9 \mathrm{~cm}$, entire or slightly crenulate, acute to acuminate, mostly. glabrous, dark green or slightly purplishtinged.Cymes axillary, expanded dichasia, sometimes forming spikes, thyrses, or panicles, sometimes reduced to solitary; bracts opposite, entire, usually green; bracteoles 2, blue or purplish.Calyx deeply 5-lobed; lobes equal or subequal; corolla funnel-shaped, tube basally with a narrowly cylindric portion, usually expanded apically into a expanded throat; limb 5-lobed; lobes usually ovate to orbicular, equal to unequal in size, contorted in bud;stamens 4, more or less didynamous, epipetalous; filaments connate in pairs at base; anthers oblong; ovary with up to 10 ovules per locule; style usually included in 
corolla tube or slightly exserted; stigma equally or unequally 2-lobed.Capsules narrowly oblong, stipitate or not, 12 - 26-seeded; septa with attached retinacula;seedsdiscoid, usually pubescent with hygroscopic trichomes.

Habitat: A weed of riparian vegetation, dams, ponds, wetlands and drainage ditches in subtropical and tropical regions.

Flowering \& Fruiting: June - December.

Specimens examined: Tripura, College-tilla, Kar et al., TUH-2733, Dated 19.11.2017

Global Distribution: Asia: Japan, India; North America; South America; Africa; Australia.

State distribution: Throughout the state of Tripura; naturalized.

Indian distribution: Maharashtra, West Bengal; common in gardens, frequently escapes and naturalized.

Use: Despite being highly weedy, the species is very popular among consumers, landscapers and gardeners (Hammer2002). It has been widely commercialized as an ornamental plant with many cultivars.

\section{Acknowledgements}

Authors are thankful to Tripura University for providing research facilities.

\section{LITERATURE CITED}

Anonymous 1997. Flora of West Bengal. Vol. 1. Botanical Survey of India, Kolkata.

Biswas, K. \& Das, A.P. 2019. Impact of invasive alien weeds on phytodiversity of TeraiDuars region of West Bengal, India. NBU J. Pl. Sci. 11: 15 - 31.

Buchholtz, K.P. 1967. Report of the terminology committee of the Weed Science Society of America. Weeds. 15: $388-389$.

Das, A.P. 2002: Survey of naturalised exotics in the flora of Darjiling Hills, West Bengal, (India). J. Econ. Tax. Bot., 26(1): $31-37$.

Das, A.P. 2011. Conservation efforts for East Himalayan Biodiversity and need for the establishment of corridors. In: C. Ghosh \& A.P. Das, Recent Studies in Biodiversity and Traditional Knowledge in India. Sarat Book House, Kolkata. Pp. 329 - 346.

Deb, D.B. 1981 and 1983. The flora of Tripura state. Volumes 1 and 2. Today and Tomorrow's Printers and Publishers, New Delhi.

Ghersa, C.M.; Roush,M.L.; Radosevich,S. R.\&Cordray,S. 1994. Co-evolution of agroecosystems and weed management. BioScience. 44: 85 - 94.

Ghersa, C.M.;Benech-Arnold, R.L.;Satorre, E.H.\&Martinez-Ghersa, M.A. 2000. Advances in weed management strategies. Field Crop Research. 67: 95 - 104.

Grubben, J. H. \& Denton, O. A. 2004. Plant Resources of Tropical Africa2 - Vegetables Wageningen, Netherlands: PROTA Foundation.

Gibbons, D.W.; Bohan, D.A. \& Rothery, P. 2006. Weed seed resources for birds in fields with contrasting conventional and genetically modified herbicide-tolerant crops. Philos. Trans. Roy. Soc. London. 273: 1921 - 1928.

Hooker, J. D. 1872-1897. Flora of British India. Vols. 1 - 7. L. Reev \& Co, Ashford, London. 
Humburg, N.E.; Colby, S.R.; Lym, R.G.; Hill, E.R.; McAvoy, W.J.; Kitchen, L.M.; \& Prasad, R.P. 1989. Herbicide Handbook of the Weed Science society of America. $6^{\text {th }}$ edn., Weed Science Society of America, Champaign, Illinois.

Hammer, R.L. 2002. Mexican Bluebell (Ruellia tweediana Griseb.) A pretty Invasive Weed. Wildland Weeds.5: 6 - 8 .

Hawes, C.; Haughton, A.J.; Bohan, D.A. \& Squire, G.R. 2009. Functional approaches for assessing plant and invertebrate abundance patterns in arable systems. Basic Applied Ecology. 10: 34 - 42.

IUCN 2000. IUCN Guidelines for the Preservation of Biodiversity Loss caused by Alien Invasive Species. IUCN, Gland, Switzerland.

Kromp, B. 1999. Carabid beetles in sustainable agriculture: a review on pest control efficacy, cultivation impacts and enhancement. Agri. Ecosys. Env. 74: $187-228$.

Kar, S. \& Datta, B. K. 2015. A glimpse of the traditional uses of plants by Koloi subtribe of Tripura. J. Bot. Soc. Beng. 69(2): 147 - 152.

Luken, J.O. \& Thieret, J.W. 1996. Amur Honeysuckle, its fall from grace. Bioscience 46: $18-24$.

Manning, R. 2004. Against the grain: how agriculture has hijacked civilization. North Point Press, New York.

McDougall, K.L.; Khuroo, A.A.; Loope, L.L.; Parks, C.G.; Pauchard, A.; Reshi, Z.A.; Rushworth, I. \& Kueffer, C. 2011.Plant Invasions in Mountains: Global Lessons for Better Management. Mount. Res. Develop. 31(4): 380 - 387.

Mittermeier, R.A.; Gil, P.R.; Hoffmann, M.; Pilgrim, J.; Brooks, T.; Mittermeier, C.G.; Lamoreux, J.; Da Fonseca, G.A.B. 2005. Hotspots Revisited: Earth's Biologically Richest and Most Endangered Terrestrial Ecoregions. Conservation International.

Moktan, S. \& Das, A.P. 2013. Diversity and distribution of invasive alien plants along the altitudinal gradient in Darjiling Himalaya,India. Pleione, 7(2): 305 - 313.

Myers, N.; Mittermeier, R. A.; Mittermeier, C. G.; da Fonseca, G. A. B. \& Kent, J. 2000.Biodiversity hotspots for conservation priorities. Nature. 403: 853-858.

Naylor, R.E.L. 2002. Weed Management Handbook. $9^{\text {th }}$ edn. British Crop Protection Enterprise, Blackwell Science, Ltd.

Prain, D. 1903. Bengal Plants. Vols. I \&II. West, Newman \& Co., London.

Raghubanshi, A.S.; Rai, L.C.; Gaur, J.P. \& Singh, J.S. 2005. Invasive Alien Species and Biodversity in India. Curr. Sci. 88(4): 539 - 540.

Rao, R. R. 1994.Biodiversity in India: Floristic Aspects. Bishen Singh Maendra Pal Singh, Dehra Dun.

Sharma, B.D. \& N.P. Balakrishnan, N.P. 1993. Flora of India, Vol. 2. Botanical Survey of India, Kolkata.

Vencill, W.K. 2002. Herbicide Handbook. 8th edn. Weed Science Society of America. Lawrence, KS. 